\title{
DETERMINANTS OF CORRUPTION PERCEPTION IN A TRANSITION COUNTRY: CASE OF ALBANIA
}

\author{
Edmond ÇERA ${ }^{1}$, Arta SINAMATI ${ }^{2}$ \\ ${ }^{1,2}$ University of Tirana, Albania \\ Corresponding author e-mail: edmond.cera@gmail.com
}

\begin{abstract}
In many aspects, Albania as a transition country has several weaknesses when compared to its neighbor countries. Even though the collapse of the communist regime was reached at almost the same time with other Balkan countries, Albania still remains outside the European Union and has to face an immature government and problematic progress in several areas. Corruption is one of the most problematic issues in Albania. This research paper is based on the data collected by IDRA Research \& Consulting and in the course of empirical analysis. It studies the relation between corruption and the microeconomic factors, categorized as demographic and socio-economic factors. In other words, this study aims to examine why some individuals are more willing to accept corruption than other. Based on prominent previous studies in this field, which were discussed to a relatively limited degree, this paper aims to build an empirical model for Albania that helps to explain why some individuals are more tolerant with regard to corruption. As previous studies have shown, such factors as gender, the area of living, region, experience or wrong conception are expected to be listed among the indicators that determine perception of corruption. This study takes into account the findings of literature review when setting up the regression. The results argue that factors such as the area of living, political orientation, the level of trust in institutions, personal experience with corruption, and the right conception of corruption are important factors determining the level of corruption perception.
\end{abstract}

Keywords: Albania, corruption perception, microeconomic factors, transition country.

\section{STUDY BACKGROUND AND LITERATURE REVIEW}

Corruption is a leap in human progress. It is not a new phenomenon, it is as old as the human history itself. Corruption is a term that refers to a wide range of behaviors. There has been strong debate over the definition of corruption. However, anti-corruption organizations, such as Transparency International and the World Bank, have agreed to pursue a definition mentioned in the study of corruption and political development by Nye (1967) "abuse of public authority for personal gain".

Apart from the challenge of finding a comprehensive definition, the second issue related to corruption is its measurement: how it can be measured. Corruption is difficult to measure, mainly because most corrupt activities are not reported. In 1995, Transparency International collected the data on corruption and formulated 
the Corruption Perception Index, listing the developing countries on the scale from 0 (very corrupt) to 10 (very honest). This index measures people's perceptions of corruption by weighing different assessments through expert surveys and data, such as World Bank Country Policies, Institutional Assessments, etc.

Amundsen ( 1999) as a scholar dedicated to the study of corruption has stated that corruption is like cancer, which affects almost all parts of society and destroys the function of its vital organs. This means that the cultural, political and economic structures of society are affected by corruption. Furthermore, according to Transparency International (1995), no country is immune to corruption. This has been evidenced by numerous corruption scandals that take place in different countries, not only in the developing and poor countries, but also in the developed countries such as Japan and the United States. Transition and developing countries are often seen as more corrupt than the developed countries. If a country is poor, it is more likely that individuals and businesses will attempt to bribe the governing administration or legislative bodies, the police, the judges, and so on.

Moreover, according to the studies on perception of corruption, in Albania it turns out that the country is not only characterized by a high levels of corruption, but also the situation has remained the same since 2010 (IDRA Institute, 2016). This research paper is encouraged by the need for an in-depth analysis with the purpose to understand better the perception of corruption in Albania. What determines individual variation in attitudes towards corruption? Why do some individuals, social groups and/or regions perceive less corruption than others? The answers to these questions, according to Moreno (2002) and Lavena (2013), can help to explain why the willingness to fight corruption can be weaker and why the willingness to participate in the corrupt actions can be stronger in some societies compared to others. Low levels of perception of corruption in an environment where the level of corruption is high are very dangerous for any attempt to eradicate corruption efficiently. It is therefore vital for policymakers to be equipped with new empirical studies on the factors that may determine the tendency of individuals to accept these anti-democratic and non-liberal behaviors.

The identification of individual factors influencing the level of perception of corruption enables in turn the identification of structural weaknesses in our institutions that shape and influence individual views, values and behaviors, creating a "culture of corruption". On the other hand, this can empower policymakers to reform these institutions and structures, affecting the extent to which individuals perceive their corruption and readiness to justify illegal actions. In short, this study contributes to discovering, strengthening and maintaining a general will in the society to fight corruption and not to participate in it.

Through our research, we have discovered a lack of previous studies, which have examined the relationship between microeconomic variables and corruption perception in the Albanian society. In this context, this study serves as a starting point in this area and tries to foster discussion in the academic and social world.

For the purposes of analysis and interpretation oriented towards the aim of the study, a research has been carried out on the possible factors that promote and influence the perception of corruption. This helped to create the framework for the analysis of relationships between the factors and perception of corruption. 


\section{Age}

Despite the increasing interest of economists in corruption determinants, age as a factor is neglected in the literature. Therefore, it is important to study possible empirical links between age and corruption. Torgler and Valev (2004) found that the justification for corruption is significantly lower for the age group above 30 years old than for the younger ones. For this determinant, the proposed hypothesis between corruption and age is:

H1: Young people tend to be more tolerant towards corruption than older ones.

Gender

Regarding corruption in particular, Swamy et al. (2000) show empirical results, which prove that women are less involved in bribery and do not accept it as much as men do. One of the reasons for these differences is said to be that men are often more likely to be in contact with public authorities, especially in highly patriarchal societies where men are considered the head of household and therefore are the ones who represent the family in many important areas. Another convincing reason why men may have a greater tendency to accept corruption as compared to women is the argument that there are differences in their competitive nature. According to Lee and Guven (2013), there are many empirical pieces of evidence in the economic literature that argue that men tend to have a much more competitive nature than females. The deduced hypothesis is:

$\mathrm{H} 2$ : Women tend to justify corruption to a lesser extent than men.

\section{Household Income}

Regarding the individual or household income level, there is a study by Jaime-Castillo \& Martinez-Cousinou (2012), which notes that income might be "a key variable in the individual capacity to engage in corrupt deals". If one considers bribery as an indicator of corruption, then it becomes logical to take into account the resources available to a rational actor. That actor is placed in a situation where he/she can choose to either engage in corruption or abstain from it. Thereby, it is highly likely that the household income has an effect on their acceptance of corruption. But in what ways exactly might income influence individual attitudes toward corruption? Firstly, people with high levels of income have more resources to invest in corrupt activities than those who are poorer. High-income individuals are the main beneficiaries of corruption, and a growth in public expenditure, therefore, multiplies the opportunities to increase their material gains through corruption. Secondly, corruption is intrinsically unfair and asymmetrical, due to the fact that it affects low income individuals most severely, because they often lack the resources needed to pay the demanded bribes in order to receive the public service to which they are entitled. In addition, they are also most vulnerable to the negative effects of the previously mentioned deviations of the public expenditure, which are a result of corruption. These previously accounted arguments can be summarized with the simplified assertion that the rich have the most to win from corruption and the least to lose, while the situation is the opposite when it comes to the poor.

$\mathrm{H} 4$ : Individuals from the households with higher income tend to justify corruption to a larger extent than individuals from the households with lower income. 


\section{Trust in Institutions}

The level of trust in institutions, according to the studies, is considered to be low and declining in contemporary democracies. However, the aspect of corruption-trust relationship and analysis of tolerance towards corruption needs to be more elaborated. Tolerance is "willingness to agree with things someone refuses" (John Sullivan, George Marcus \& James Piereson, 1979).

H5: The higher the trust in the institutions, the lower the perception of corruption.

\section{Experience with Corruption}

The level of corruption perception may change among citizens who have previous experience with corruption compared to others. Specifically, citizens who experience corrupt practices may have confidence in political institutions. A positive relationship between the experience of corruption and tolerance was reported by Chang and Huang (2016). On the other hand, in the observations made public, it has been noted that citizens who base their perception on the basis of conversations with friends or third-party sources such as media and social networks, tend to express a higher rating in relation to corruption compared to those citizens who support their assessment of personal experience (IDRA Institute, 2016). While the two sources of reviewed literature contradict each other, this paper suggests the following hypothesis:

H6: People who experience corruption are more likely to perceive less corruption than others.

\section{Area of living}

Regarding the area of living, the literature findings show that there is a significant difference of corruption perception between those who live in urban areas compared to those living in rural areas (H7). This finding is reported by Melgar, Rossi, Smith (2010). Next subchapter describes the methodology of the research.

\section{METHODOLOGY}

This study is based on the primary data collected by IDRA Institute in Albania. The database summarizes the data and answers from Albanian citizens in the period January-February 2016; the poll conducted is nationally representative.

According to the survey methodology, corruption is measured as a perception by the respondents, giving a rating of 1 to 10 to some institutions and representative personalities of the country, where 1 means "completely honest" and 10 "fully corrupt" (for more, see IDRA Institute, 2016).

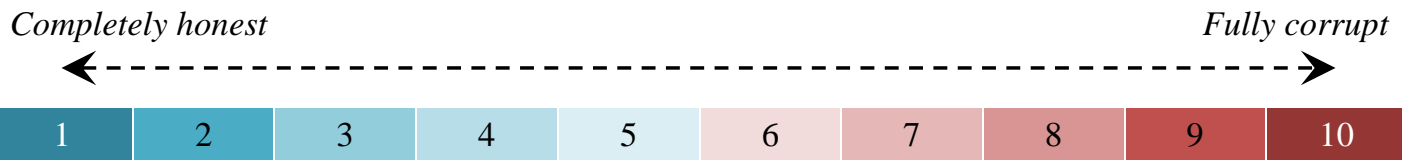

In this paper, we calculate an aggregated index of estimations that are taken for all institutions, which is the average of all estimations given by the individual. In other words, consider the following scheme: 


\section{Estimated institution}

\begin{tabular}{|c|c|c|}
\hline $\begin{array}{l}\text {-Deputies } \\
\text {-Mayors } \\
\text {-Ministers } \\
\text {-Policemen } \\
\text {-Lectors } \\
\text {-Religious leaders } \\
\text {-Judges } \\
\text {-Servicemen }\end{array}$ & $\begin{array}{l}\text {-Political Leaders } \\
\text {-NGOs Directors } \\
\text {-Prosecutors } \\
\text {-Doctors } \\
\text {-Media } \\
\text {-President of the } \\
\text { Republic } \\
\text {-Customs Officers } \\
\text {-Tax Officers }\end{array}$ & $\begin{array}{l}\text {-Businessmen } \\
\text {-Teachers } \\
\text {-Regional Officers of } \\
\text { Real Estate } \\
\text {-Officers of National } \\
\text { Defense Inspectorate } \\
\text { of the Territory } \\
\text {-Municipal Police } \\
\text {-State Police } \\
\text {-Prime Minister }\end{array}$ \\
\hline
\end{tabular}

Aggregate index

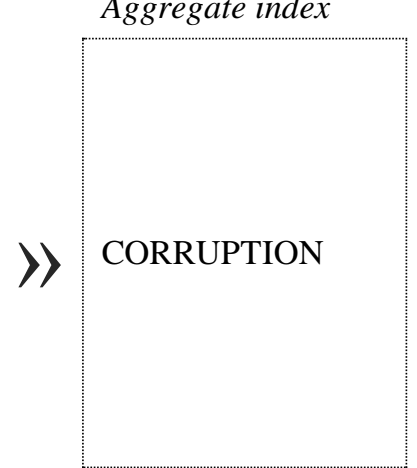

This aggregated indicator serves as a factor explained or determined (lefthand side of the equation) by dimensions and other aspects related to individual characteristics. Taking into account both literature review findings and our expectations regarding the factors, in case of the model discussed in this material, the following summary is considered.

Table 1. Factors and Hypotheses (Operationalization of the Concept)

\begin{tabular}{|l|l|l|}
\hline Factor & Measure & $\begin{array}{l}\text { Assumed relationship with perception of corruption } \\
\text { (hypotheses) }\end{array}$ \\
\hline Corruption & Interval (1-10) & Dependent variable \\
\hline Gender & $\begin{array}{l}0=\text { female, } \\
1=\text { male }\end{array}$ & $\begin{array}{l}\text { Women tend to justify corruption to a lesser extent than } \\
\text { men }\end{array}$ \\
\hline Age & Scale & Young people have more tolerance towards corruption \\
\hline $\begin{array}{l}\text { Household } \\
\text { income }\end{array}$ & $\begin{array}{l}\text { Categorical }(3 \\
\text { categories })\end{array}$ & $\begin{array}{l}\text { For Albanian households, the level of income in relation } \\
\text { to the perception of corruption is not significant }\end{array}$ \\
\hline Area & $\begin{array}{l}0=\text { urban, } \\
1=\text { rural }\end{array}$ & $\begin{array}{l}\text { People living in urban area perceive more corruption } \\
\text { than those from rural areas }\end{array}$ \\
\hline $\begin{array}{l}\text { Political } \\
\text { orientation }\end{array}$ & $\begin{array}{l}1=\text { socialist }, \\
0=\text { other }\end{array}$ & $\begin{array}{l}\text { People with political orientation on the same side with } \\
\text { the ruling party give a lower rating to corruption }\end{array}$ \\
\hline $\begin{array}{l}\text { Interaction with } \\
\text { the police }\end{array}$ & $\begin{array}{l}1=\text { interaction, } \\
0=\text { no interaction }\end{array}$ & $\begin{array}{l}\text { Those who have had interaction with the police over the } \\
\text { past } 12 \text { months give a lower rating to corruption }\end{array}$ \\
\hline $\begin{array}{l}\text { Trust in } \\
\text { institutions }\end{array}$ & $\begin{array}{l}\text { Interval }(0-10) \\
\text { Experience with } \\
\text { corruption }\end{array}$ & $\begin{array}{l}\text { The higher the trust in institutions, the lower the } \\
\text { perception of corruption }\end{array}$ \\
\hline $\begin{array}{l}\text { Right } \\
\text { conception }\end{array}$
\end{tabular}

*As a corruption variable, trust in institutions is computed as the aggregate of all assessments expressed for the listed public institutions.

The questionnaire tries to distinguish between one who understands correctly the corruption through the question "During the holiday season, the owner of a flower shop increases the prices of flowers. Do you think the owner is corrupt?" Those who positively answer to this question are considered to wrongly conceive corruption. 
The model used is a regression, which assumes the relationship between the factors in a linear form and can be written in the general form as follows:

$$
y=f\left(x_{1}, \ldots, x_{n}\right) \Rightarrow \underbrace{\text { Corruption }}_{\text {defined factor }}=\beta_{0}+\underbrace{\beta_{1} x_{1}+\ldots+\beta_{n} x_{n}}_{\text {defining factors }}+\varepsilon
$$

where $x$ marks the defining variables, the beta coefficient $(\beta)$ shows the relationship between the dependent variable ( $\beta_{0}$ denotes the intercept of the model) and epsilon $(\varepsilon)$ is the residual of the model. The parameters of this model are estimated using SPSS professional program by executing the Ordinary Least Squares method.

\section{ANALYSIS AND RESULTS}

In dealing with the model and through its development, different kinds of models were examined, each trying to better explain the phenomenon of corruption. The first test takes into account all of the aforementioned factors, assuming each of them conveys a perceived corruption influence to a linear form.

The empiric model reports that gender, interaction with the police, age, household income level, and whether people live in the capital or not, are not important factors for the perception of corruption in Albania. In other words, women in Albania do not tend to justify corruption to a lesser extent than men do; furthermore, youngsters do not have a significantly different level of perception compared to older ones. It is important to point out that, as explained below, in case of Albania household income does not have any impact on the level of corruption perceived - the regression did not confirm our hypothesis. On the other hand, according to the model estimations, factors such as the rural/urban area of living, political orientation, the level of trust in institutions, personal experience with corruption, and the right conception of corruption, are important factors in determining the level of corruption perception. In case of urbanity, the data show that those who live in rural area express a lower perception on corruption than those form urban area and this confirmed our hypothesis. According to the results, it is obvious that political leaning is evident in Albania: people with political orientation on the same side with the ruling party give a lower rating to corruption. It is worth pointing out that this study confirms the consideration of Chang and Huang (2016) regarding the positive relationship between the level of perceived corruption and personal experience with corruption situations. The model confirmed our hypothesis on the relationship of trust in institutions with corruption. Summarizing the findings, the empirical analysis (part of which is represented in the table below) highlights the following: 
Table 2. Acceptance and Refusal of Hypotheses

\begin{tabular}{|c|c|c|c|}
\hline $\begin{array}{l}\text { Factor or } \\
\text { variable }\end{array}$ & $\begin{array}{l}\text { Coefficient } \\
\text { sign \& } \\
\text { significance }\end{array}$ & $\begin{array}{l}\text { Assumed relationship with perception of } \\
\text { corruption (hypotheses) }\end{array}$ & Decision \\
\hline Gender & $\left(+^{\circ}\right)$ & $\begin{array}{l}\text { Women tend to justify corruption to a lesser extent } \\
\text { than men }\end{array}$ & $\begin{array}{l}\text { Not } \\
\text { confirmed }\end{array}$ \\
\hline Age & $\left(-^{\circ}\right)$ & Young people have more tolerance for corruption & $\begin{array}{l}\text { Not } \\
\text { confirmed }\end{array}$ \\
\hline $\begin{array}{l}\text { Household } \\
\text { income }\end{array}$ & $\left(-^{\circ}\right)$ & $\begin{array}{l}\text { For Albanian households, the level of income in } \\
\text { relation to the perception of corruption is not } \\
\text { significant }\end{array}$ & Confirmed \\
\hline $\begin{array}{l}\text { Area of } \\
\text { living }\end{array}$ & $(-* *)$ & $\begin{array}{l}\text { People living in urban area perceive more corruption } \\
\text { than those from rural areas }\end{array}$ & Confirmed \\
\hline $\begin{array}{l}\text { Political } \\
\text { orientation }\end{array}$ & $(-* * *)$ & $\begin{array}{l}\text { People with political orientation on the same side } \\
\text { with the ruling party give a lower rating to corruption }\end{array}$ & Confirmed \\
\hline $\begin{array}{l}\text { Interaction } \\
\text { with police }\end{array}$ & $\left(+^{\circ}\right)$ & $\begin{array}{l}\text { Those who have had interaction with police over the } \\
\text { past } 12 \text { months give a lower rating to corruption }\end{array}$ & $\begin{array}{l}\text { Not } \\
\text { confirmed }\end{array}$ \\
\hline $\begin{array}{l}\text { Trust in } \\
\text { institutions }\end{array}$ & $(-* * *)$ & $\begin{array}{l}\text { The higher the trust in the institutions, the lower the } \\
\text { perception of corruption }\end{array}$ & Confirmed \\
\hline $\begin{array}{l}\text { Experience } \\
\text { with } \\
\text { corruption }\end{array}$ & $(+* * *)$ & $\begin{array}{l}\text { People with personal experience in at least one } \\
\text { corruptive situation over the past } 12 \text { months express } \\
\text { lower perception of corruption }\end{array}$ & $\begin{array}{l}\text { Not } \\
\text { confirmed }\end{array}$ \\
\hline $\begin{array}{l}\text { Right } \\
\text { conception }\end{array}$ & $(+* * *)$ & $\begin{array}{l}\text { Those who conceive the concept of corruption } \\
\text { correctly, perceive more corruption }\end{array}$ & Confirmed \\
\hline Capital & $\left(-^{\circ}\right)$ & People living in capital perceive more corruption. & $\begin{array}{c}\text { Not } \\
\text { confirmed }\end{array}$ \\
\hline
\end{tabular}

Further studies focusing on this issue may shed light on it. Interesting would be a comparison between determinants of Albanians perception of corruption with those of our neighbour countries, where can be pointed out roles of culture, political context and other countries characteristics as well.

\section{CONCLUSION}

Through attempting to understand better the phenomenon of corruption, this study makes its contribution relying on the empirical data. The analysis conducted within this study reveals that the perception of corruption depends on several aspects of the individual nature. Based on the empirical findings of the study, it should be highlighted that in the case of Albania and in the context of the study, gender, age, interaction with the police, the level of income and the fact whether people live in the capital or not, are not relevant to the perception of corruption in the country.

* Note that " $+/-$ " indicates a positive/negative linear relationship with the dependent variable, whereas the significance of each variable is indicated by ${ }^{\circ}$ which denotes $n o$ significance; * significance with $90 \%$ confidence level; ** $95 \%$ confidence level and *** $99 \%$ confidence level. 
In other words, their perception does not represent significant differences with their counterparty. Obvious differences in the perception of corruption are evident considering the living area, where those living in the city perceive more corruption than those in the rural area; political orientation, those who are in favor of the ruling party give a lower assessment of corruption compared to others. Trust in institutions also correlates negatively with the perception of corruption, supporting both the expectations and the findings of previous research.

It is argued that those who have experienced at least one corruptive situation over the past 12 months express a lower perception of corruption than others who do not have such experiences. The finding of this study is also the confirmation of the hypothesis that someone who does not confuse the concept of corruption with something else perceives a higher level of corruption than the rest of the public.

\section{REFERENCES}

Amundsen, I. (1999). Political Corruption: An Introduction to the Issues. Bergen: Chr. Michelsen Institute: Working Paper 99:7.

Chang, E. C. C. \& Huang, S.-h. (2016). Corruption Experience, Corruption Tolerance, and Institutional Trust in East Asian Democracies. Taiwan Journal of Democracy, 12(1), 27-44.

IDRA Institute. (2016). Corruption in Albania: perceptions and experiences 2015-2016. Tirana.

Jaime-Castillo, A. M., \& Martinez-Cousinou, G. (2012). Distributive effects and moral justification of corruption. Conference paper presented at Second ISA Forum of Sociology 2012.

Lavena, C. F. (2013). What Determines Permissiveness Toward Corruption? Public Integrity, 15(4), 345-366. https://doi.org/10.2753/pin1099-9922150402

Lee, W.-S., \& Guven, C. (2013). Engaging in Corruption: The Influence of Cultural Values and Contagion Effectsat the Micro Level. Journal of Economic Psychology, 39, 287-300. https://doi.org/10.1016/j.joep.2013.09.006

Melgar, N., Rossi, M., \& Smith, T. W. (2010). The perception of corruption in a cross-country perspective: why are some individuals more perceptive than others? Economia Aplicada, 14(2), 183-198. https://doi.org/10.1590/s1413-80502010000200004

Moreno, A. (2002). Corruption and Democracy: A Cultural Assessment. Comparative Sociology, 1(3), 495-507. https://doi.org/10.1163/156913302100418556

Nye, J. S. (1967). Corruption and Political Development: A Cost-Benefit Analysis. American Political Science Review, 61(02), 417-427. https://doi.org/10.2307/1953254

Sullivan, J. L., Piereson, J., \& Marcus, G. E. (1979). An Alternative Conceptualization of Political Tolerance: Illusory Increases 1950s-1970s. American Political Science Review, 73(03), 781-794. https://doi.org/10.2307/1955404

Swamy, A. V., Lee, Y., Azfar, O., \& Knack, S. (2000). Gender and Corruption. IRIS Center Working Paper No. 232, 33 p. https://doi.org/10.2139/ssrn.260062

Torgler, B., \& Valev, N. T. (2004). Corruption and age, Working paper No. $2004-24$.

Transparency International. (1995). Corruption Perceptions Index: Early Editions. Retrieved from Transparency International https://www.transparency.org/research/cpi/cpi_early/0

\section{ACKNOWLEDGMENT}

Authors thank IDRA Research \& Consulting, a market research company in Tirana, for allowing them to use its survey data set. This made it possible for the authors to elaborate an empirical study about corruption in Albania. 


\section{AUTHORS' SHORT BIOGRAPHIES}

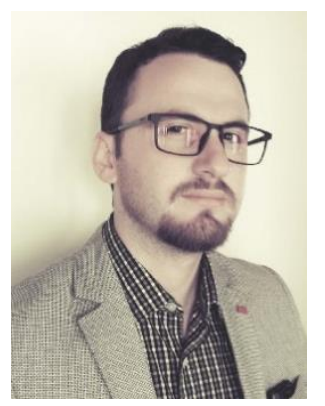

Edmond Çera received M.Sc. degree in Finance and Accountability from the Agricultural University of Tirana.

$\mathrm{He}$ is an assistant at the University of Tirana, Faculty of Economics, Finance Department: responsible for conducting lectures on finance and economic fields/subjects (portfolio management, basics of finance, international finances). At the same time, Mr. Çera is also working as an analyst at IDRA Research and Consulting: responsible for providing statistical background for the correct explanation of the results and indexes. Previously, he was a specialist at the Prime Minister's Office. He is a coauthor of several research papers published in international scientific journals.

Since 2014, he is a member of the Editorial Board at Albanian Centre for Risk, a non-profit research and scientific center registered in Tirana.

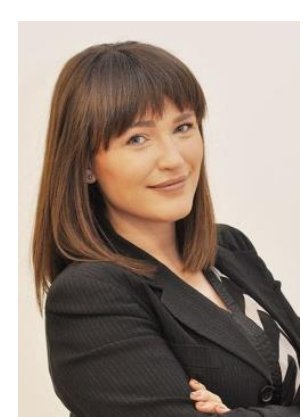

Arta Sinamati received M.Sc. degree in Finance from Faculty of Economics, University of Tirana, in 2015.

She is currently working as a Researcher at University of New York Tirana Her first job after graduating was a Coach of International Online Investments at Stock International Albania (an affiliate company of Lead Capital Markets Ltd), conducting lessons and seminars on "FOREX", "CFDs", "Psychology of Trading", "Fundamental and Technical Analysis", for clients and new employees. She used to work in areas of employment, business and import/export. Ms. Sinamati has participated in some national conferences focusing on and discussing high-level importance issues of Albanian society and economy. 